\title{
Validity and Reliability of the Korean Version of the Women's Toileting Behavior Scale
}

\author{
Aeyoung So ${ }^{1}$, Jennie C. De Gagne ${ }^{2}$, Sunah Park ${ }^{1}$ \\ ${ }^{1}$ Department of Nursing, Gangneung-Wonju National University, Wonju, Korea \\ ${ }^{2}$ Duke University School of Nursing, Durham, NC, USA
}

\begin{abstract}
Purpose: The purpose of this study was to investigate the validity and reliability of the Korean version of the Toileting Behavior Scale (KTBS) to assess women's toileting behavior related to urinary elimination.

Methods: The original English version, the Toileting Behavior: Women's Elimination Behaviors scale, was translated into Korean with forward and backward translation. Examinations of internal consistency reliability, construct validity using exploratory factor analysis and confirmatory factor analysis, item convergent validity, and discriminant validity were conducted with SPSS/WIN 23.0 and AMOS/WIN 23.0 software. Concurrent validity was examined with the International Consultation on Incontinence Questionnaire-Short Form.

Results: Cronbach $\alpha$ for the overall scale was 0.78 , and the 5 subscales ranged from 0.79 to 0.94 . The exploratory factor analysis revealed 5 factors for the 17 -item scale. Confirmatory factor analysis supported good convergent and discriminant values $(\lambda=0.49-0.96$, critical ratio $=4.51-15.68>1.97, \mathrm{P}<0.05$, construct reliability $=0.72-0.97)$. The concurrent validity was supported by correlation with the International Consultation on Incontinence Questionnaire-Short Form $(r=0.146, P=0.011)$. Conclusions: The KTBS (17 items) is an appropriate tool to measure older Korean women's toileting behavior with good validity and reliability.
\end{abstract}

Keywords: Behavior; Psychometrics; Urinary incontinence; Women

- Grant/Fund Support: This research was supported by a grant from the Gangneung-Wonju National University in 2016.

- Research Ethics: This study was approved by the Institutional Review Board of the Gangneung-Wonju National University (approval number: GWNU-2016-27).

- Conflict of Interest: No potential conflict of interest relevant to this article was reported.

\section{INTRODUCTION}

Urinary incontinence (UI) is a common disease observed in $28.4 \%-70.5 \%$ of women and closely related to quality of life in Korea $[1,2]$. Existing studies reported that involuntary leakage of urine causes emotional stress such as humiliation, anxiety, and worries about using the toilet, and the odor of urine affect interpersonal relationships and social activity, leading depression in severe cases [3]. Nonetheless, the help-seeking behavior of women with UI is poor due to the perception that UI is part of the normal aging process and their embarrassment about having a health issue that involves the female reproductive system [4].

Toileting behavior refers to an action of emptying the blad-
Corresponding author: Sunah Park (iD https://orcid.org/0000-0001-9164-997X Department of Nursing, Gangneung-Wonju National University, 150 Namwonro, Heungeop-myeon, Wonju 26403, Korea

E-mail: suna73@gwnu.ac.kr / Tel: +82-33-760-8644 / Fax: +82-33-760-8641

Submitted: January 16, 2019 / Accepted after revision: February 27, 2019 (i) (7) This is an Open Access article distributed under the terms of the Creative Commons Attribution Non-Commercial License (http://creativecommons.org/licenses/by-nc/4.0/) which permits unrestricted non-commercial use, distribution, and reproduction in any medium, provided the original work is properly cited. 
der, which includes voiding place, voiding time, voiding position, and voiding style [5]. Women with UI often go to the toilet frequently or void prematurely without any urge to prevent unexpected leakage of urine. Such toileting behavior has a negative impact on bladder function, deteriorating symptoms of UI [6]. Regarding voiding position, individuals may void in a crouching position because of concerns that the buttocks may touch the toilet seat. This interferes with pelvic muscle relaxation and the complete emptying of the bladder [7]. Therefore, early assessment and management of toileting behaviors will help prevent UI in healthy women and symptom deterioration in women with UI.

Wang and Palmer $[8,9]$ developed the Toileting Behavior: Women's Elimination Behaviors (TB-WEB) Scale to assess toileting behaviors in middle-aged women with incontinence. In other countries, studies had been reported to identify the relationship of women's toileting behaviors with UI using the TBWEB scale [10-12]. These studies found that most of the women showed premature voiding, straining voiding, and delayed voiding behaviors [10-12]. In Korea, it is also needed to examine the toileting behaviors of women to improve UI management. Therefore, this study is to investigate whether the TBWEB scale is applicable to the Korean population. Given that the prevalence of UI increases with age and low level of education and difficulty in using a computer in Korean older women, a paper-based questionnaire is necessary. Therefore, the purpose of this study was to examine the validity and reliability of Korean version of the Toileting Behavior Scale (KTBS) to establish the basis for the use of tools to measure toileting behaviors among Korean women with UI.

\section{MATERIALS AND METHODS}

\section{Design}

A methodological study design was used to test the validity and reliability of the KTBS.

\section{Sample}

Subjects were recruited from 1 public health center and 3 primary health care posts based in Gangwon Province of Korea. Subject selection criteria were women aged 50 or older who did not have problems in cognitive function and were able to communicate. The sample size was required 150-200 for exploratory factor analysis (EFA) [13], and 130-200 for confirmatory factor analysis (CFA) given that the number of factors was 5
[14]. Thus, the questionnaire was distributed to a total of 330 women (each 165 for EFA and CFA) considering the dropout rate, and 321 questionnaires were analyzed excluding 9 with missing answers.

\section{Measurement}

Toileting Behavior: Women's Elimination Behaviors (TB-WEB)

TB-WEB [8] consists of 18 items with 5 subscales including place preference for voiding (items TB1, TB2, TB3, and TB4), premature voiding (items TB5, TB6, TB7, TB8, and TB9), delayed voiding (items TB10, TB11, and TB12), straining voiding (items TB14, TB15, TB16, and TB17), and position preference for voiding (items TB13 and TB18). Items responses are on a 5 -point scale ranging from 1 (never) to 5 (always). Higher scores indicate unhealthier toileting behavior. The reliability of the 5 subscales was Cronbach $\alpha=0.70-0.88$ when originally developed.

\section{International Consultation on Incontinence Questionnaire-Short Form (ICIQ-SF)}

For the concurrent validity, the KTBS was hypothesized to be related to symptoms of UI, based on previous studies $[8,10]$. The symptom of UI was measured using the ICIQ-SF scale [15]. It comprises three scored items (frequency, amount, overall impact on quality of life) and an unscored self-diagnostic item for episodes of urine leakage. The total score was calculated as the sum of the responses to 3 items and ranged 1-21. Higher scores indicate greater severity of UI [15]. The Korean version of the ICIQ-SF scale translated by the Korean Continence Society was used after obtaining permission from Dr. Nikki Cotterill, the developer of the English version. The reliability of the original instrument was Cronbach $\alpha=0.95$ [14]. In the current study, Cronbach $\alpha$ was 0.83 .

\section{Research procedures Translation of the instrument}

The questionnaire was translated into Korean by the 2 authors (AS, SP) with permission. A back-translation was made by 2 bilingual speakers without viewing the original English version. The authors discussed and modified the translation together with the backward translators to investigate whether the intention of the original English instrument had been accurately translated. The KTBS was finalized through this double-check process. 


\section{Data collection}

Ethical approval for the study was obtained from the Institutional Review Board of the Gangneung-Wonju National University (GWNUIRB-2016-27) before data collection. Data were collected by 5 home-visit nurses from the public health center and 3 community nurse practitioners from December 2016 to February 2017. Prior to data collection, the authors had a meeting with the surveyors to discuss study objectives, protection of personal information, and survey contents. Written consent was obtained from participants, and a small reward was provided for them upon the completion of the survey.

\section{Data analysis}

Data were analyzed using IBM SPSS Statistics ver. 23.0 (IBM Co., Armonk, NY, USA) and IBM SPSS AMOS 23.0 (IBM Co.). The construct validity was tested through EFA and CFA. According to the recommendation for use of separate samples to perform EFA and CFA [16], a sample of 150 subjects for EFA were selected using the random sampling method provided in IBM SPSS Statistics ver. 23.0, and the remaining 171 were used for CFA. For EFA, a principal components analysis with varimax rotation was applied. The Kaiser-Meyer-Olkin (KMO) and Bartlett's sphericity test were conducted prior to an EFA to test sample size adequacy and the correlation between the items. The factor loading standards for determining the number of extracted factors were eigenvalue 1.0 or higher, and factor loading 0.40 or higher.

For CFA, the following absolute fit indices were examined to test the model's fit: chi-square minimization (CMIN), chi- square minimization/degree of freedom (CMIN/DF), goodness of fit index (GFI), root mean square residual index (RMR), standardized root mean square residual (SRMR), and root mean squared error of approximation. In addition, normal fit index (NFI), comparative fit index (CFI), and Tucker-Lewis Index (TLI) were calculated using incremental fit index. Parsimonious goodness of fit index (PGFI) and parsimonious normed fit index (PNFI) were identified as a parsimonious fit index. Akaike information criterion (AIC), Bayes information criterion (BIC), and consistent Akaike information criterion (CAIC) are used to select the best model between KTBS I (the original instrument with 18 items) with KTBS II (17 items in which 1 item not meeting the factor loading standard deleted from CFA).

Discriminant validity was analyzed by testing whether the latent average variance extracted (AVE) was greater than the square of correlation coefficient and the value of correlation coefficient $\pm 2 \times$ standard error did not equal 1 . To assess the concurrent validity, we analyzed the correlation between the ICIQ-SF score and the KTBS score. The internal consistency reliability was examined using Cronbach $\alpha$.

\section{RESULTS}

\section{General characteristics of the subjects}

The average age of all subjects was $74.35 \pm 9.36$ years. Regarding UI-related characteristics, the average voiding frequency for daytime and nighttime was $4.88 \pm 2.32$ times and $2.35 \pm 1.63$ times, respectively. The total mean score of ICIQ-SF was $4.03 \pm 4.77$. The general characteristics and UI-related charac-

Table 1. Homogeneity test for general and UI-related characteristics of participants $(\mathrm{N}=321)$

\begin{tabular}{|c|c|c|c|c|c|c|}
\hline Characteristic & No. ${ }^{\text {a) }}$ & Total & $\operatorname{EFA}(n=150)$ & $\mathrm{CFA}(\mathrm{n}=171)$ & $\chi^{2}$ or $t$ & P-value \\
\hline Age (yr) & 318 & $74.35 \pm 9.36(50-94)$ & $74.13 \pm 9.69$ & $74.54 \pm 9.09$ & -0.39 & 0.697 \\
\hline Body mass index $\left(\mathrm{kg} / \mathrm{m}^{2}\right)$ & 318 & $24.25 \pm 3.54(16.65-36.52)$ & $24.23 \pm 3.48$ & $25.01 \pm 12.25$ & -0.75 & 0.453 \\
\hline Parity & 319 & $4.16 \pm 2.12(0-11)$ & $4.01 \pm 2.06$ & $4.29 \pm 2.16$ & -1.21 & 0.227 \\
\hline Menopause age & 242 & $48.08 \pm 5.61(29-66)$ & $48.02 \pm 5.30$ & $48.14 \pm 5.92$ & -0.17 & 0.865 \\
\hline Frequency of day urination & 321 & $4.88 \pm 2.32(1-30)$ & $4.99 \pm 2.76$ & $4.77 \pm 1.80$ & 0.85 & 0.398 \\
\hline Frequency of night urination & 320 & $2.35 \pm 1.63(0-10)$ & $2.34 \pm 1.59$ & $2.36 \pm 1.67$ & -0.15 & 0.319 \\
\hline Prevalence of UI & 318 & $130(40.9)$ & $63(42.9)$ & $67(39.4)$ & 0.33 & 0.570 \\
\hline Scores of ICIQ-SF & 320 & $4.03 \pm 4.77(0-20)$ & $4.06 \pm 4.83$ & $4.01 \pm 4.73$ & 0.10 & 0.919 \\
\hline
\end{tabular}

Values are presented as mean \pm standard deviation (range) or number (\%).

UI, urinary incontinence; EFA, exploratory factor analysis; CFA, confirmatory factor analysis; ICIQ-SF, International Consultation of Incontinence Questionnaire-Short Form.

${ }^{\text {a) }}$ Missing data are excluded. 
teristics between the EFA and CFA groups were homogenous (Table 1).

\section{Validity test \\ Construct validity}

Exploratory factor analysis: The KMO index for EFA was 0.74 for the KTBS, satisfying the sample adequacy standard of 0.5 . The significance value of the Bartlett's test of sphericity was $<0.001$, satisfying the standard $<0.05$ [16]. The number of factors was selected using eigenvalue 1 or more and scree chart as the selection criterion, and the total variance explained was more than $60 \%$. Through the primary EFA (KTBS I, 18 items), items with a factor loading of 0.40 or higher in all items were selected [17] and 5 factors were selected based on the analysis results. With regard to item TB4, the factor loadings of factors 3 and 4 were 0.55 and 0.48 , respectively. The item was found to overlap in 2 factors. Although the factor loading of factor 3 (0.55) was higher than that of factor 4 (0.48), the reliability test of the factors revealed that belonging to factor 4 increased the reliability value more than belonging to factor 3 . Hence, it was decided to classify item TB4 under factor 4 (Table 2).

In CFA (Table 3), the factor loading $(\lambda)$ of item TB 3 was 0.28 , far less than 0.50 . Hence, another EFA (KTBS II, 17 items) with the removal of item TB3 was conducted, and the values

Table 2. Rotated factor loadings to exploratory factor analysis and reliability $(\mathrm{n}=150)$

\begin{tabular}{|c|c|c|c|c|c|c|c|}
\hline \multirow{2}{*}{ Items } & \multirow{2}{*}{ Abbreviated item description } & \multicolumn{5}{|c|}{$\mathrm{KTBS} \mathrm{I}^{\mathrm{a})}\left(\mathrm{KTBS}^{\mathrm{i}} \mathrm{II}^{\mathrm{b}}\right)$} & \multirow{2}{*}{$\operatorname{ITC}(r)$} \\
\hline & & $\mathrm{F} 1$ & $\mathrm{~F} 2$ & F3 & $\mathrm{F} 4$ & F5 & \\
\hline TB 1 & Worry about sanity in public toilets & $-0.03(0)$ & $0.14(0.03)$ & $0.29(0.11)$ & $0.79(0.89)$ & $0.02(0.03)$ & 0.64 \\
\hline TB 2 & Avoid public toilets & $0.02(0.07)$ & $0.11(0.05)$ & $0.40(0.29)$ & $0.76(0.87)$ & $0.02(0.02)$ & 0.70 \\
\hline TB 3 & Empty the bladder at home & $0.21(-)$ & $-0.05(-)$ & $-0.15(-)$ & $0.66(-)$ & $0.03(-)$ & 0.26 \\
\hline TB 4 & Try to wait until I come home & $-0.10(-0.06)$ & $-0.04(0.01)$ & $0.55(0.37)$ & $0.48(0.62)$ & $-0.05(-0.13)$ & 0.49 \\
\hline TB 5 & Void without desire: At home & $0.47(0.60)$ & $0.14(0.19)$ & $0.37(0.14)$ & $0.02(0.28)$ & $-0.11(0.03)$ & 0.37 \\
\hline TB 6 & At leaving home & $0.76(0.76)$ & $-0.00(0.05)$ & $-0.09(-0.09)$ & $0.11(-0.06)$ & $0.02(-0.01)$ & 0.56 \\
\hline TB 7 & At home of someone else's & $0.83(0.84)$ & $0.15(0.11)$ & $0.03(0.01)$ & $-0.06(-0.04)$ & $0.08(0.10)$ & 0.69 \\
\hline TB 8 & At a public place & $0.81(0.74)$ & $0.15(0.21)$ & $-0.00(0.02)$ & $-0.08(-0.15)$ & $0.02(0.02)$ & 0.64 \\
\hline TB 9 & Just in case (preventive) & $0.79(0.80)$ & $0.07(0.08)$ & $0.07(0.10)$ & $0.234(0.11)$ & $0.09(0.03)$ & 0.66 \\
\hline TB 10 & Try to delay voiding if I'm busy & $-0.01(-0.07)$ & $-0.04(-0.01)$ & $0.81(0.75)$ & $0.040(0.24)$ & $0.02(0.04)$ & 0.63 \\
\hline TB 11 & Restrain the desire as long as possible & $0.04(0.08)$ & $-0.03(0)$ & $0.84(0.86)$ & $0.11(0.25)$ & $0.13(0.09)$ & 0.73 \\
\hline TB 12 & Restrain the desire at work & $0.10(0.12)$ & $0.04(0)$ & $0.81(0.86)$ & $0.14(0.12)$ & $0.12(0.03)$ & 0.71 \\
\hline TB 14 & Strain to initiate urinating & $0.01(0.10)$ & $0.56(0.89)$ & $-0.12(0.02)$ & $0.14(0.05)$ & $-0.00(0.93)$ & 0.41 \\
\hline TB 15 & Strain during the whole urinating process & $0.12(0.11)$ & $0.92(0.93)$ & $0.03(0.02)$ & $0.00(0.02)$ & $0.03(0.07)$ & 0.71 \\
\hline TB 16 & Strain to empty the bladder completely & $0.16(0.20)$ & $0.92(0.93)$ & $-0.01(-0.06)$ & $0.03(0.04)$ & $0.04(0.02)$ & 0.75 \\
\hline TB 17 & Strain to empty the bladder faster & $0.13(0.15)$ & $0.83(0.84)$ & $0.13(0.02)$ & $-0.06(0)$ & $0.06(-0.01)$ & 0.60 \\
\hline TB 13 & Sit down on the seat & $0.09(0.09)$ & $0.04(0.06)$ & $0.08(0.07)$ & $-0.01(-0.06)$ & $0.92(0.93)$ & 0.71 \\
\hline TB 18 & Squat on/Hover over the toilet & $0.04(0.04)$ & $0.06(0.07)$ & $0.11(0.06)$ & $0.05(0.02)$ & $0.92(0.94)$ & 0.71 \\
\hline \multicolumn{2}{|c|}{ Eigenvalue } & $2.90(2.96)$ & $20.82(30.35)$ & $20.79(20.31)$ & $10.99(20.19)$ & $10.76(10.81)$ & \\
\hline \multicolumn{2}{|c|}{ Explained variance (\%) } & $16.12(17.41)$ & $150.67(190.71)$ & $150.43(130.59)$ & $110.07(120.90)$ & $90.75(100.63)$ & \\
\hline \multicolumn{2}{|c|}{ Cumulative explained variance (\%) } & $16.12(17.41)$ & $310.80(370.12)$ & $420.23(500.71)$ & $580.30(630.61)$ & $680.05(740.24)$ & \\
\hline \multicolumn{2}{|c|}{ Cronbach alpha value total: $0.76(0.78)$} & $0.79(0.79)$ & $0.71(0.94)$ & $0.83(0.83)$ & $0.72(0.81)$ & $0.83(0.83)$ & \\
\hline
\end{tabular}

TB, Toileting Behavior; ITC, item-total correlation; KTBS, Korean version of the Toileting Behavior Scale.

KTBS I (KTBS II): Kaiser-Meyer-Olkin, 0.74 (0.74): Bartlett test, $\chi^{2}, 2,567.579$ (2,501.045); P-value, $<0.001(<0.001)$.

The shading refers to 5 factors extracted from the exploratory factor analysis by selecting items with a factor loading of 0.40 or higher in all items; F1, premature voiding; F2, straining voiding; F3, delayed voiding; F4, place preference for voiding; F5, position preference for voiding.

a) The original instrument with 18 items. ${ }^{\text {b) }}$ Seventeen items in which 1 item not meeting the factor loading standard deleted from confirmatory factor analysis. 


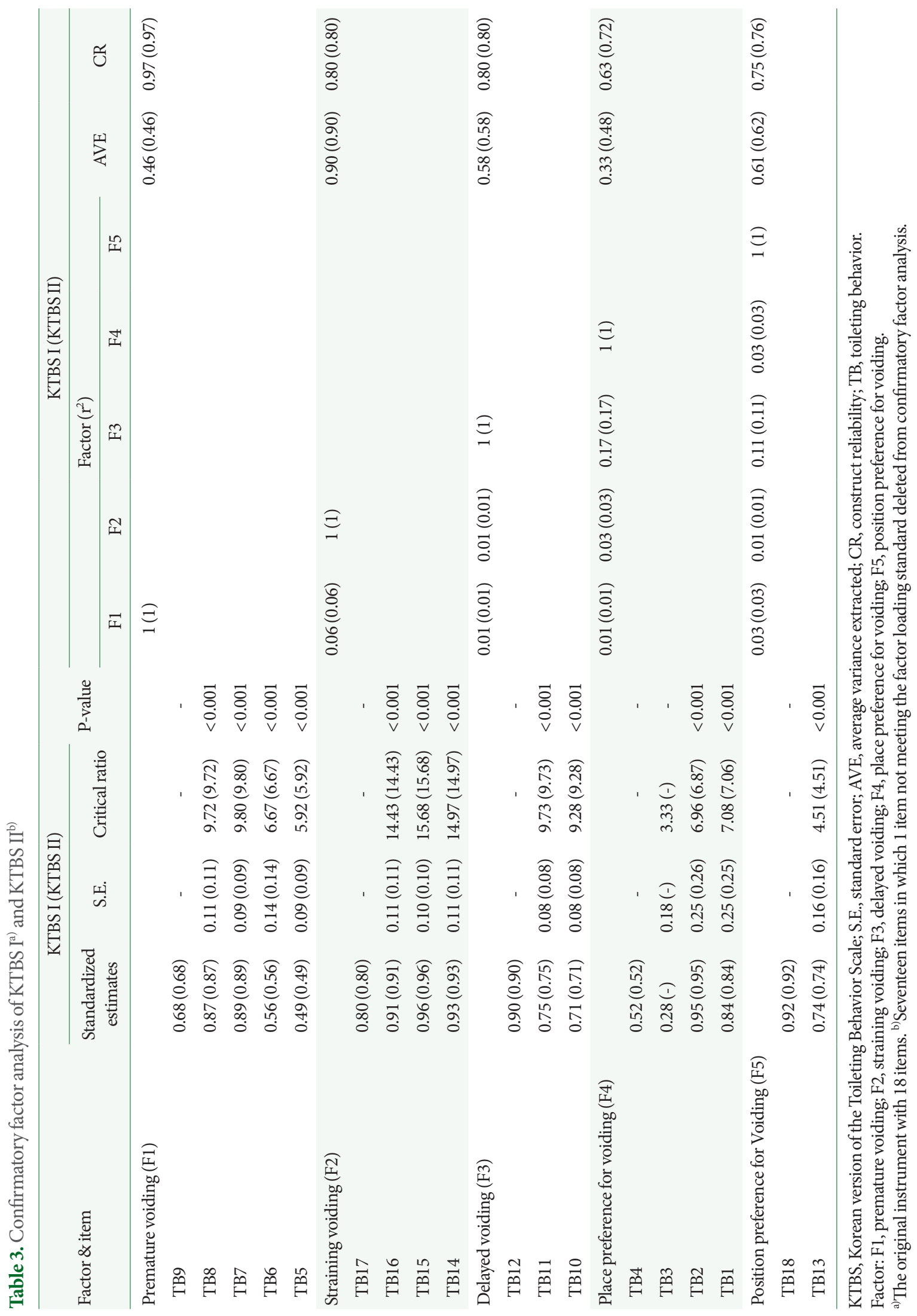


appear in parenthesis in Table 2. Finally, the KTBS II was composed of 17 items and 5 factors. The cumulative explained variance increased from $60 \%$ (KTBS I) to $74.24 \%$ (KTBS II). The loading of each factor ranged from 0.60 to 0.94 . The explained variance of each factor was as follows: factor 1, 17.41\%; factor 2 , $19.71 \%$; factor $3,13.59 \%$; factor $4,12.90 \%$; and factor $5,10.63 \%$ (Table 2).

Confirmatory factor analysis: CFA was conducted to test the relationships between the 5 factors selected through EFA and the items assigned to each factor. The regression imputation [18] was applied to handle missing data prior to AMOS analysis. The convergent validity was verified whether critical ratio was significant while the standardized factor loading ( $\lambda$ value) was at least 0.5 . Item TB3 recorded 0.28 , far below the factor loading standard, and was thus eliminated. As a result, the standardized factor loading values satisfied the standard ( 0.40 or higher), ranging between $0.49-0.96$. The critical ratio for significance ranged between 4.51 and 15.68, all meeting the standard (=1.97). Hence, all paths were statistically significant $(\mathrm{P}<0.05)$. AVE was between 0.46-0.90 except for item TB3. Factors 2 and 4 were close to the standard 0.50 , being 0.46 and 0.48 respec- tively. The other factors (1, 3, and 5) satisfied the standard, ranging between $0.58-0.90$. Construct reliability was between $0.72-0.97$, with all 5 factors satisfying the standard $(=0.70)$ [19]. The convergent validity was thus confirmed (Table 3).

The fit index values of the KTBS I (18 items) and KTBS II (17 items) were compared (Table 4). In the KTBS I, model fit indices were $\mathrm{CMIN} / \mathrm{DF}=1.95, \mathrm{AGFI}=0.81, \mathrm{RMR}=0.10, \mathrm{SRMR}=0.80$, $\mathrm{NFI}=0.87, \mathrm{CFI}=0.93, \mathrm{TLI}=0.92, \mathrm{PGFI}=0.63$, and $\mathrm{PNFI}=0.71$. Most of the values of KTBS II were either within the normal value range or on the boundary: $\mathrm{CMIN} / \mathrm{DF}=1.94, \mathrm{AGFI}=0.82$, $\mathrm{RMR}=0.09, \mathrm{SRMR}=0.07, \mathrm{NFI}=0.87, \mathrm{CFI}=0.94, \mathrm{TLI}=0.92$, $\mathrm{PGFI}=0.62$, and PNFI $=0.71$. The overall fit index values of KTBS II were slightly improved compared with those of KTBS I. For the KTBS II, AIC $=299.542, \mathrm{BIC}=437.517$, and $\mathrm{CAIC}=481.517$, while for the KTBS IAIC $=335.952, \mathrm{BIC}=480.199$, and $\mathrm{CAIC}=526.199$. The smaller the value of these indices is, the better the model [20]. Therefore, it was concluded that it is reasonable to adopt the KTBS II with item TB3 excluded in terms of goodness of fit.

Discriminant validity: Discriminant validity was tested to determine whether the scale's factors were unrelated with each other. The AVE was greater than the squared correlation, and

Table 4. Goodness-of-fit indexes for KTBS ${ }^{\mathrm{a})}$ and $\mathrm{KTBS}^{\mathrm{b}}{ }^{\mathrm{b})}$

\begin{tabular}{|c|c|c|c|}
\hline Index & KTBS I (model 1) & KTBS II (model II) & Creteria \\
\hline \multicolumn{4}{|l|}{ Absolute fit index } \\
\hline CMIN $\left(\chi^{2}\right)($ P-value $)$ & $243.95(<0.001)$ & $211.54(<0.001)$ & $>0.05$ \\
\hline CMIN/DF & 1.95 & 1.94 & $\leq 3$ \\
\hline GFI & 0.86 & 0.87 & $\geq 0.90$ \\
\hline AGFI & 0.81 & 0.82 & $\geq 0.90$ \\
\hline RMR & 0.10 & 0.09 & $\leq 0.08$ \\
\hline SRMR & 0.08 & 0.07 & $\leq 0.08$ \\
\hline RMSEA (90\% CI) & $0.08(0.06-0.09)$ & $0.07(0.06-0.09)$ & $\leq 0.08$ \\
\hline \multicolumn{4}{|l|}{ Incremental fit index } \\
\hline NFI & 0.87 & 0.88 & $\geq 0.90$ \\
\hline CFI & 0.93 & 0.94 & $\geq 0.90$ \\
\hline TLI & 0.92 & 0.92 & $\geq 0.90$ \\
\hline \multicolumn{4}{|l|}{ Parsimonious fit index } \\
\hline PGFI & 0.63 & 0.62 & $0.6-0.9$ \\
\hline PNFI & 0.71 & 0.71 & $0.6-0.9$ \\
\hline $\mathrm{AIC}$ & 335.952 & 299.542 & Lower score is better. \\
\hline $\mathrm{BIC}$ & 480.199 & 437.517 & \\
\hline CAIC & 526.199 & 481.517 & \\
\hline
\end{tabular}

KTBS, Korean version of the Toileting Behavior Scale; CMIN/DF, chi-square minimization/degree of freedom; GFI, goodness of fit index; AGFI, adjusted goodness of fit index; RMR, root mean square residual; SRMR, standardized root mean square residual; RMSEA, root mean squared error of approximation; CI, confidence interval; NFI, normal fit index; CFI, comparative fit index; TLI, Tucker-Lewise index; PGFI, parsimonious goodness of fit index; PNFI, parsimonious normed fit index; AIC, Akaike information criterion; BIC, Bayes information criterion; CAIC, consistent Akaike information criterion.

a) The original instrument with 18 items. ${ }^{\text {b) }}$ Seventeen items in which 1 item not meeting the factor loading standard deleted from confirmatory factor analysis. 
Table 5. Discriminant and concurrent validity

\begin{tabular}{|c|c|c|c|c|c|c|c|}
\hline Validity & Factor & $\begin{array}{c}\text { Factors (KTBS II), } \\
\mathrm{r}\left(\mathrm{r}^{2}\right)\end{array}$ & AVE & Estimate & S.E. $\times 2$ & $\begin{array}{c}\text { Estimate } \pm 2 \\
\times \text { S.E }\end{array}$ & Evaluation \\
\hline \multirow[t]{11}{*}{ Discriminant validity } & $\mathrm{F} 1 \leftrightarrow \mathrm{F} 2$ & $0.25(0.06)$ & 0.90 & 0.25 & 0.07 & $0.18-0.31$ & $\neq 1$ \\
\hline & $\mathrm{F} 1 \leftrightarrow \mathrm{F} 3$ & $0.12(0.01)$ & - & 0.12 & 0.08 & $0.04-0.20$ & $\neq 1$ \\
\hline & $\mathrm{F} 1 \leftrightarrow \mathrm{F} 4$ & $0.17(0.03)$ & - & 0.17 & 0.05 & $0.11-0.22$ & $\neq 1$ \\
\hline & $\mathrm{F} 1 \leftrightarrow \mathrm{F} 5$ & $0.12(0.01)$ & - & 0.12 & 0.09 & $0.03-0.21$ & $\neq 1$ \\
\hline & $\mathrm{F} 2 \leftrightarrow \mathrm{F} 3$ & $0.11(0.01)$ & 0.46 & 0.11 & 0.15 & $-0.04-0.26$ & $\neq 1$ \\
\hline & $\mathrm{F} 2 \leftrightarrow \mathrm{F} 4$ & $0.08(0.01)$ & - & 0.08 & 0.10 & $-0.02-0.17$ & $\neq 1$ \\
\hline & $\mathrm{F} 2 \leftrightarrow \mathrm{F} 5$ & $0.18(0.03)$ & - & 0.18 & 0.17 & $0.01-0.36$ & $\neq 1$ \\
\hline & $\mathrm{F} 3 \leftrightarrow \mathrm{F} 4$ & $0.42(0.17)$ & 0.58 & 0.42 & 0.15 & $0.27-0.57$ & $\neq 1$ \\
\hline & $\mathrm{F} 3 \leftrightarrow \mathrm{F} 5$ & $0.33(0.11)$ & - & 0.33 & 0.22 & $0.11-0.56$ & $\neq 1$ \\
\hline & $\mathrm{F} 4 \leftrightarrow \mathrm{F} 5$ & $0.18(0.03)$ & 0.48 & 0.18 & 0.15 & $0.03-0.32$ & $\neq 1$ \\
\hline & $\mathrm{F} 5 \leftrightarrow \mathrm{F} 1$ & $0.12(0.01)$ & 0.62 & - & - & - & - \\
\hline Concurrent validity & \multicolumn{7}{|c|}{$\mathrm{KTBS} \mathrm{II}^{\mathrm{a})}$ : r (P-value), $0.212(<0.001)$} \\
\hline
\end{tabular}

KTBS, Korean version of the Toileting Behavior Scale; AVE, average variance extracted; S.E., standard error; ICIQ-SF, International Consultation on Incontinence Questionnaire-Short Form.

Factor: F1, premature voiding; F2, straining voiding; F3, delayed voiding; F4, place preference for voiding; F5, position preference for voiding.

a) Seventeen items in which 1 item not meeting the factor loading standard deleted from confirmatory factor analysis.

the value of correlation coefficient $\pm 2 \times$ standard error did not equal 1 . Thus, the factors were proven to be discriminant with each other (Table 5).

Concurrent validity: As hypothesized, the KTBS II scores were significantly correlated with the ICIQ-SF scores $(r=0.21$, $\mathrm{P}<0.001$ ). The concurrent validity was proven (Table 5).

\section{Reliability test}

The item-total correlation coefficient of the original instrument KTBS I (18 items) was 0.26-0.75. If the item-total correlation coefficient is under 0.30 , the item is unrelated to the factor, and if it is over 0.80 , it should be removed for the item for being a duplication [21]. Thus, item TB3 with 0.26 was removed for not meeting the standard. The rest of the items all ranged between 0.37-0.75. This provides evidence for adopting KTBS II (17 items). With item TB3 removed, the reliability of the overall KTBS II was Cronbach $\alpha=0.78$, slightly increasing from the preremoval value of 0.76 . The reliability of the subscales was 0.79-0.94 (Table 2).

\section{Final instrument (KTBS)}

The final instrument consists of 5 factors and 17 items: 5 items on factor 1 (premature voiding), 4 on factor 2 (straining voiding), 3 on factor 3 (delayed voiding), 3 on factor 4 (place preference for voiding), and 2 on factor 5 (position preference for voiding) (Appendix I).

\section{DISCUSSION}

To the best of our knowledge, the current study is the first to evaluate the psychometric properties of the TB-WEB scale using both EFA and CFA, while previous studies $[8,12]$ explored the validity through only EFA. The results of the EFA showed that the 18 items (KTBS I) were identically classified as the 5 subscales of the original instrument (i.e., premature voiding, straining voiding, delayed voiding, place preference for voiding, position preference for voiding). In a Swedish TB-WEB study [12], subscales were classified into 5 as the original instrument in the EFA.

In the CFA of the KTBS' 18 items following the EFA, however, the factor loading of the item TB3 ("I try to void before leaving home") was low, recording 0.28 . The original instrument classified it under place preference for voiding, emphasizing home being a place for voiding. However, we have determined that the item TB3 can be a preventive premature voiding behavior before leaving home. In this case, the question can be classified into premature voiding, and the explained variance of the subscale position preference for voiding for item TB3 may be low. According to a qualitative study on Korean elderly women [22], women with UI showed a premature voiding behavior to prevent involuntary urination while outside home. The major cause of this behavior was worries about not being able to find a toilet while outside home. As such, item TB3 can 
be interpreted differently by each respondent as one may void at home before going out for not wanting to use the public toilet, as well as for the possible inaccessibility to toilet. For this reason, item TB3 was removed. Another EFA of the remaining 17 items (KTBS II) was conducted after eliminating item TB3. The explained variance and loading of the 5 subscale concepts increased when compared with the 18 items. In addition, the item-total correlation of the item TB3 was 0.26 in the correlation analysis of correlation with all items. In general, items with an item-total correlation under 0.30 are considered to have little contribution in a scale [23]. Based on this theory [23], removing the item was considered valid. This study demonstrated that it is imperative to conduct both EFA and CFA at the same time for accurate testing of an instrument's validity.

In the CFA, the fit indices of the revised model excluding item TB3 (KTBS I) improved overall compared with the original model (KTBS II). In addition, when comparing these 2 models using the values of AIC, BIC, and CAIC, the indices of the revised model (KTBS II) were smaller, thus these results suggest that the revised model (KTBS II) is more fitted. Regarding the concurrent validity, this study showed that the ICIQ-SF score was correlated with the KTBS II. Previous studies $[8,10]$ also found that there was a difference between toileting behaviors and UI symptoms measured with the ICIQ-SF. Considering bladder training is one of the primary treatments for UI, it is important to assess the toileting behavior to help women with UI control and manage their symptoms.

In this study, the overall Cronbach $\alpha$ of the KTBS II was 0.78 and subscales' Cronbach $\alpha$ was ranged from 0.79 to 0.94 , Hence, this scale was evaluated to be an internally consistent instrument measuring toileting behavior in older women.

This study confirmed that the KTBS II had good reliability, content, and construct validity. The items on the KTBS are phrased relatively simply, thus the scale is highly applicable to toileting behavior evaluation and improvement. In addition, this study established an instrument that uses and assesses toileting behavior as an intervention to prevent and manage UI in women. This study suggests that the assessment and intervention of the toileting behavior using the KTBS be actively carried out to prevent and improve UI in community-dwelling women.

\section{ACKNOWLEDGEMENTS}

The authors are grateful to home visiting nurses, community health practitioners and women for their participation in this study. We also would like to thank Drs. Mary H. Palmer and Kefang Wang for the permission of use the TB-WEB instrument.

\section{AUTHOR CONTRIBUTION STATEMENT}

- Full access to all the data in the study and takes responsibility for the integrity of the data and the accuracy of the data analysis: $A S$

- Study concept and design: $A S, J C D$

- Acquisition of data: $A S, S P$

- Analysis and interpretation of data: $A S$

- Drafting of the manuscript: $A S, S P$

- Critical revision of the manuscript for important intellectual content: $J C D, S P$

- Statistical analysis: $A S$

- Obtained funding: $A S$

- Administrative, technical, or material support: $A S, S P$

-Study supervision: $J C D$

\section{REFERENCES}

1. Kim OB, Yoon H. Prevalence of urinary incontinence, single voided volume, post void residual volume, daytime frequency, and nocturia in women over 40 years. Korean J Adult Nurs 2013:25:679-89.

2. Lee YS, Lee KS, Jung JH, Han DH, Oh SJ, Seo JT, et al. Prevalence of overactive bladder, urinary incontinence, and lower urinary tract symptoms: results of Korean EPIC study. World J Urol 2011; 29:185-90.

3. Coyne KS, Kvasz M, Ireland AM, Milsom I, Kopp ZS, Chapple CR. Urinary incontinence and its relationship to mental health and health-related quality of life in men and women in Sweden, the United Kingdom, and the United States. Eur Urol 2012;61:88-95.

4. Lee KS, Sung HH, Na S, Choo MS. Prevalence of urinary incontinence in Korean women: results of a National Health Interview Survey. World J Urol 2008;26:179-85.

5. Wang K, Palmer MH. Women's toileting behaviour related to urinary elimination: concept analysis. J Adv Nurs 2010;66:1874-84.

6. Willis-Gray MG, Wu JM, Sripad A, Newman D, Palmer MH. Toileting behaviors in women presenting to a urogynecology clinic. Urol Nurs 2017:37:251-5.

7. Moore KH, Richmond DH, Sutherst JR, Imrie AH, Hutton JL. Crouching over the toilet seat: prevalence among British gynaecological outpatients and its effect upon micturition. Br J Obstet Gynaecol 1991;98:569-72. 
8. Wang K, Palmer MH. Development and validation of an instrument to assess women's toileting behavior related to urinary elimination: preliminary results. Nurs Res 2011;60:158-64.

9. Angelini KJ, Newman DK, Palmer MH. Psychometric evaluation of the toileting behaviors: women's elimination behaviors scale in a sample of college women. Female Pelvic Med Reconstr Surg 2019 Mar 15 [Epub]. https://doi.org/10.1097/SPV.0000000000000711.

10. Palmer MH, Newman DK. Women's toileting behaviours: an online survey of female advanced practice providers. Int J Clin Pract 2015;69:429-35.

11. Wan X, Wu C, Xu D, Huang L, Wang K. Toileting behaviours and lower urinary tract symptoms among female nurses: A cross-sectional questionnaire survey. Int J Nurs Stud 2016;65:1-7.

12. Sjögren J, Malmberg L, Stenzelius K. Toileting behavior and urinary tract symptoms among younger women. Int Urogynecol J 2017;28:1677-84.

13. Hinkin TR. A brief tutorial on the development of measures for use in survey questionnaires. Organ Res Methods 1998:1:104-21.

14. Mundfrom DJ, Shaw DG, Ke TL. Minimum sample size recommendations for conducting factor analyses. Int J Test 2005:5:15968.

15. Avery K, Donovan J, Peters TJ, Shaw C, Gotoh M, Abrams P. ICIQ: a brief and robust measure for evaluating the symptoms and impact of urinary incontinence. Neurourol Urodyn 2004;23:322-30.

16. Lee CY. Advanced nursing statistics. Paju (Korea): Soomoonsa; 2016. p. 189-233.

17. Hair JF, Black WC, Babin BJ, Anderson RE. Multivariate data analysis: a global perspective. 7th ed. Upper Saddle River (NJ): Pearson Prentice Hall; 2010. p. 109-136, 609-732.

18. Kim WP. Structural equation model analysis. Seoul (Korea): Wisein company; 2017. p. 9, 171-3.

19. Yu JP. The concept and understanding of structural equation modeling. Seoul (Korea): Hannare Publishing Co.; 2012, p. 160-370.

20. Ro KS. Statistical analysis for research paper writing- SPSS \& AMOS 21. Seoul (Korea): Hanbit Academy, Inc.; 2018, p. 295-303.

21. Field AP. Discovering statistics using IBM SPSS statistics: and sex and drugs and rock 'n' roll. 4th ed. London: Sage; 2013. p. 685-6.

22. Park S, Yeoum S, Kim Y, Kwon HJ. Self-management experiences of older Korean women with urinary incontinence: a descriptive qualitative study using focus groups. J Wound Ostomy Continence Nurs 2017;44:572-7.

23. Lee EO, Lim NY, Park HA, Lee IS, Kim JI, Bae J, et al. Nursing research and statistics. Paju (Korea): Soomoonsa; 2009. 
Appendix 1. Korean version of the Toileting Behavior Scale (KTBS)

\begin{tabular}{|c|c|c|c|c|c|c|c|}
\hline \multirow{2}{*}{$\begin{array}{c}\text { 번호 } \\
\text { (KTBS) }\end{array}$} & \multirow{2}{*}{$\begin{array}{l}\text { 원도구 } \\
\text { 번호 } \\
\text { (TB) }\end{array}$} & \multirow[t]{2}{*}{ 내용 } & $\begin{array}{l}\text { 전혀 } \\
\text { 아니다 }\end{array}$ & $\begin{array}{l}\text { 드물게 } \\
\text { 그렇다 }\end{array}$ & $\begin{array}{l}\text { 보통 } \\
\text { 그렇다 }\end{array}$ & $\begin{array}{l}\text { 자주 } \\
\text { 그렇다 }\end{array}$ & $\begin{array}{l}\text { 항상 } \\
\text { 그렿다 }\end{array}$ \\
\hline & & & (1) & (2) & (3) & (4) & (5) \\
\hline 1 & TB1 & 공중 화장실을 이용할 때 더러울까봐 걱정된다. & & & & & \\
\hline 2 & TB2 & 공중 화장실을 이용하지 않으려고 노력한다. & & & & & \\
\hline 3 & TB4 & 외출 시에는 집에 도착할 때까지 소변을 참으려고 한다. & & & & & \\
\hline 4 & TB5 & 집에 있을 때 소변이 마렵지 않아도 화장실을 간다. & & & & & \\
\hline 5 & TB6 & 외출 시에 소변이 마렵지 않아도 화장실을 간다. & & & & & \\
\hline 6 & TB7 & $\begin{array}{l}\text { 친구나 친지 등의 집에 있을 때, 소변이 마렵지 않아도 } \\
\text { 화장실을 간다. }\end{array}$ & & & & & \\
\hline 7 & TB8 & $\begin{array}{l}\text { 사람이 많은 공공장소(예: 상점, 직장, 음식점등)에 있을 } \\
\text { 때, 소변이 마렵지 않아도 소변을 본다. }\end{array}$ & & & & & \\
\hline 8 & TB9 & 만약을 대비해 소변이 마렵지 않아도 소변을 본다. & & & & & \\
\hline 9 & TB10 & 바쁠 땐 소변보는 것을 미룬다. & & & & & \\
\hline 10 & TB11 & 더 이상 참을 수 없다고 느낄 때까지 소변을 참는다. & & & & & \\
\hline 11 & TB12 & $\begin{array}{l}\text { 일(=직장) 나가서는 소변이 매우 마렵거나 샐 정도까지 } \\
\text { 기다렸다가 화장실을 간다. }\end{array}$ & & & & & \\
\hline $12 *$ & TB13 & 소변을 볼 때 변기에 앉아서 본다. & & & & & \\
\hline 13 & TB14 & $\begin{array}{l}\text { 소변을 보는 동안 계속 잘 나오도록 배를 조이거나 힘을 } \\
\text { 준다. }\end{array}$ & & & & & \\
\hline 14 & TB15 & 소변을 끝까지 보기 위해 배를 조이거나 힘을 준다. & & & & & \\
\hline 15 & TB16 & 소변을 빨리 보기 위해 배를 조이거나 힘을 준다. & & & & & \\
\hline 16 & TB17 & 소변을 보기 시작할 때, 배를 조이거나 힘을 준다. & & & & & \\
\hline 17 & TB18 & $\left\{\begin{array}{l}\text { 소변을 볼 때 엉덩이를 약간 } \\
\text { 들어 변기에 닿지 않도록 하거나 } \\
\text { 쪼그리고 앉아 본다. }\end{array}\right.$ & & & & & \\
\hline
\end{tabular}

*reversed item

제 1 요인 (조기배뇨): $4,5,6,7,8$

제 2 요인 (복압배뇨): $13,14,15,16$

제 3 요인 (지연배뇨): 9, 10, 11

제 4요인 (배뇨장소선호): $1,2,3$

제 5요인 (배뇨자세선호): 12,17 